\title{
STREET VENDING: MEANS OF LIVELIHOOD FOR THE URBAN POOR AND CHALLENGE FOR THE CITY ADMINISTRATION IN ETHIOPIA

\author{
https://doi.org/10.47743/jopafl-2021-19-09
}

\author{
Elias BERHANU \\ Department of Public Administration and Development Management \\ Addis Ababa University, Ethiopia \\ elias.berhanu@aau.edu.et
}

\begin{abstract}
Street vending in Ethiopia is a very important yet unbridled component of the informal sector. In the context of the current demographic dynamics and absence of sufficient job opportunities, street vending has become an important economic shelter for the urban poor. The key reasons for joining street vending include the small capital requirement, lack of access to credit facilities, and lack of suitable and commercially viable trading outlets. Street vendors use their personal savings, family transfers and informal credits as start-up capital. Street vendors generate by far better income than they used to get in their original villages. The social network is vital for joining the sector. The common narrative that operators in the informal sector are mainly with no formal education is frequently attacked as more people with formal education, including school dropouts, high-school completes and college graduates, are rapidly joining the sector. One of the major effects of street vending in Addis Ababa is the disruption in pedestrians' free movement and vehicle traffic. Presence of large crowd of vendors in a given space is the function of the size (volume) of items carried by an individual vendor. Formal shop owners identify street vendors as unfair competitors. Many people in Addis are accustomed to "shopping" at the streets since vendors offer merchandise at relatively lower prices. Street vending has unregulated feature whereby the government loses tax income which could have been collected had the transactions taken place legally. Local governments are forced to allocate huge budgets to hire as many officers to control street businesses. However, given the recurrent rise in the crowd of immigrants and weakness of institutions, the task of regulating street business is becoming almost unfeasible. In Ethiopia, the economic and social significance of street vending is not yet well studied and articulated to guide state policy directions aimed at alleviating urban poverty.
\end{abstract}

Keywords: Informal Sector, Street Vending, Domestic Immigrants, the Urban Poor, Megenagna

\section{Introduction}

The dualistic nature of the economy of the LDCs is described by the parallel existence of a modern (urban, industrial, capital intensive) and traditional (rural, agrarian, labor intensive) sectors (Todaro and Smith, 2012; Todaro, 1997). When the analysis of the dualistic feature is applied to the urban economy, it is based on the dichotomy between the formal and informal sectors. According to Dewar and Watson, in Elias (2014), the informal sector plays a vital role for those who need or desire to generate income outside the 'formal sector' The majority of new comers to the urban labor market often strive to create their own employment or to work for micro and small-scale enterprises engaged in diverse economic activities. Macharia, cited in Elias (2014), describes the informal sector as "[...] all those small scale business activities that operate without direct state regulation." Wandscheider (ibid) complements that "the more informal is the enterprise, the more interactions with government agencies are often kept to a minimum". Assuming an "ideal market economy", without any level of regulation, the difference between formal and informal would be totally meaningless as all business activities become entirely "informal” 
(Castelles and Portes 1989:13). Moreover, "the more a society institutionalizes its economic activities following collectively defined power relationships and the more individual actors try to escape this institutionalized logic, the sharper the divide between the two sectors" (ibid).

Large proportion of the urban population, which embraces more of domestic immigrants in SSA, finds employment in the informal sector (Loop 2000:19). Studies show that the informal sector accounts for more than $60 \%$ of the "non-agricultural employment" in developing countries (ILO, 2013; Chen, 2012). LEDNA (2011) discloses that the informal sector contributes to $77 \%$ of non-agricultural employment and $55 \%$ of the GDP in SSA. Moreover, it is imperative to see the fact that informal activities are not confined to the economic realities of developing countries alone since such engagements also occur in advanced countries (Castells and Portes, 1989).

In Africa, strategies developed for promoting informal sector enterprises not only serve employment creation purposes, but can also be taken as measures of "direct attack on poverty" (Dewar and Watson, cited in Elias 2014). The role of the informal economy goes beyond providing employment opportunities for the poor; if properly "engaged", it could enhance "the fiscal base of local governments" (UN-HABITAT 2009: 2). In view of this, [...] "any analysis of Africa's economy that does not focus on informality" can be seen as totally deficient (Macharia, cited in Elias 2005). Unfortunately, macroeconomics tends to focus only on the formal sector activities and generally has little concern for the informal sector (Pederson 2000:131; ILO 2009).

Street vending is a very important and increasingly proliferating component of the informal sector, particularly in LDCs. Academic discourse on street vending does not afford to ignore the genesis of the concept and salient features of the informal sector. Street vending engages people (street vendors), essentially the urban poor (resident and domestic immigrants), who sell items of different assortments for pedestrians and irregular customers of the general public in streets, lanes, sidewalks, footpaths, pavements, public parks or any other public place or private areas, from temporary built up structures or by moving from place to place (Pinki, 2015).

The literature in this material deals with brief discussions on the informal sector and its theoretical foundations. The discussion extends into the features of street vending with a focus on causes, virtues and challenges of the sector. A brief description of research methods is provided after the review of related literature. The data collected from primary and secondary sources will be analyzed and presented using mixed methods of analysis, mainly with a focus on qualitative approach. The focus of the study is on street vending in one of the busiest city centers and business hubs of Addis Ababa, namely Megenagna. This area of the city is characterized by heavy concentration of street vending, assumed to providing means of income earning for the urban poor, including the resident poor and domestic immigrants.

\section{The Informal Sector}

The concept of informal sector was introduced into the international discourse by ILO in the 1970s when it launched a series of large, multi-disciplinary "employment missions" to various developing countries to study the impact of the 1960s development strategies on peoples' livelihoods. The Kenya Employment Mission, in its official report, 
recognized that the former traditional sector which was expected to wither away and give way to a modern sector, had not just persisted but had expanded to include "profitable and efficient enterprises" as well as marginal activities (ILO, 1972). To highlight this fact, the mission chose to use the term 'informal sector' rather than 'traditional sector' for the range of small-scale and unregistered economic activities. The sector is named "informal" since it is not officially licensed by the pertinent government agency. It is not engaged in taxation. The informal sector does not need formal regulation, high capital, permanent working place, higher education or well organized training. Without these qualities, it is open for anyone who wants to join the sector (ILO, 1972). Seven criteria were identified to distinguish the sector: ease of entry, unregulated and competitive markets, reliance on indigenous resources, family ownership of enterprises, small scale of operation, labor intensive and adapted technology, and skills acquired outside of the formal school system (ILO, 1972). Moreover, the ILO 1993 International Conference on Labor Statistics (ICLS) described the informal sector as “... consisting of units engaged in the production of goods or services with the primary objective of generating employment and income to the person concerned”. The informal sector is recognized by different nomenclatures as the informal economy, the unofficial economy, the shadow economy, the parallel economy, the transient economy and many more.

\section{Theoretical viewpoints}

There have been various schools of thoughts and debates on the subject matter of the "informal sector". The schools provide explanations for the reasons why informal sectors exist and persist. They hold contending perspectives regarding the salient features of the informal economy. Here, some of the major ones, including the dualist, modernist and structural, Marxist and dependency, neo-liberalist, legalist and voluntarist schools are briefly discussed.

The Dualistic Perspective is traced to the Arthur Lewis's labor market theory of the 1950s which divides economies of developing countries into two as the modern (urban) industrial sector and the traditional (rural) agricultural sector. The modern sector is described by capitalist mode of production, capital accumulation and economic growth whereas the traditional sector is described by pre-capitalist mode of production and agrarian subsistence with mere survivalist level of production (ILO, 2002; Chaudhuri and Mukhopadhyay, 2009; Chen, 2012). Lewis's surplus labor theory assumes availability of unlimited supply of unskilled labor in the traditional rural sector, which will be sooner or later absorbed by the modern industrial sector. In the dualist labor market approach informal employment is considered as involuntary solution to unemployment, a temporary coping strategy till job opportunities are available in the modern formal sector (Todaro and Smith 2012; Todaro, 1997). This school views the informal sector at large and street vending in particular as comprising marginal activities that provides income for the poor and a safety net in times of risk (ILO, 1972). The Dualists promote the notion that street vending business has small linkages to the formal economy as it operates in a distinct, marginalized and separate sector.

According to the Modernization Perspective, the informal sector is a marginalized sector characterized by survival activities of the urban poor. Informal business was seen either as a residue from a pre-modern era that is gradually disappearing or as a part of the 
pre-modern economic order surviving only on the fringes of modern society. This thinking is rooted in the assumption that informal economic sector is a residual labor class which is destined to disappear (Cross \& Morales 2007, Bromley, 2000). As it should not indefinitely exist, the informal sector has to give way to or eventually get integrated with the formal modern sector. The Structural Perspective, on the other hand, focuses on the structure of formal and informal relationships as part of a unified economic system instead of viewing the informal sector as separate from the formal economic sector (Barnes, 2012; Chaudhuri and Mukhopadhyay, 2009; Chen, 2012; ILO, 2002). One typical case of the main linkages between the formal and informal sectors is the provision of low cost goods and services to the formal sector's work force. Engagement in the informal sector is necessity-driven since marginalized people resort to join it in the absence of alternative ways of securing livelihood (Castells and Portes, 1989).

According to the Marxist Perspective, unemployment and underemployment is caused by the profit maximization motive of the capitalist system. A reserve of unemployed and underemployed population is beneficial to the capitalist mode of production since it increases cheap labor supply and decreases wage rates. This approach argues that the informal sector is not merely linked to, but also is a necessary condition for the existence of the modern capitalist accumulation, specifically with its potential to lower consumption and lower costs within the formal sector (Barnes, 2012). In the Dependency Perspective, the informal sector is seen a subordinate to and its change condition dependent upon the dynamics of the formal sector. Its visibility as an alternative weakens when the formal sector is strong and expands when the formal sector is weak or is in crisis (ibid). Those engaged in the informal sector serve to reduce input and labor costs and, thereby, increase the competitiveness of large capitalist firms. The informal and formal businesses are intrinsically linked. Informal enterprises and wage workers are subordinated to the interests of capitalist development, providing cheap goods and services (Moser, 1978; Castells and Portes, 1989).

The Neo-Liberal Perspective focuses on the assumptions of a rational economic choice. In recent years, participation in street entrepreneurship has been redefined as a rational economic choice. For the neo-liberals, informal entrepreneurs are the ones who break the hurdles created by burdensome state machinery. Such entrepreneurs make a rational economic choice to escape over-regulation of the formal sector. The development of the informal sector is not due only to the labor market dynamics (i.e., surplus labor) but basically due to costs of government regulations that induced small-scale entrepreneurs towards informal activity. This perspective views the informal sector not as an involuntary substitute for insufficient job creation, but a voluntary cost-saving strategy for small business owners trying to avoid excessive government regulation. Business venture in the informal sector is a direct by-product of the advent of a de-regulated open world economy (Castells and Portes, 1989).The neo-liberal school suggests deregulation of the market, abolition of state intervention (appreciation of the role of a minimalist state) in the economy.

Like the neo-liberal perspective, the Legalist Perspective sees street vending business as comprised of "plucky" micro entrepreneurs who choose to operate informally in order to avoid the costs, time and effort of formal registration. The Legalists argue that a hostile legal system leads the self-employed to operate informally with their own informal extra-legal norms. They argue that states should introduce easy bureaucratic rules and 
procedures to encourage informal enterprises to register and operate formally (Chen, 2005). According to Chen (2012), those who work informally have one thing in common: they lack legal and social protection. This view attributes the division of formal and informal economies to the legal, bureaucratic position of the state. In this approach, the legal status is the main element distinguishing informal from formal activities. Proponents of the neoliberal and legalist perspectives often adopted views similar to the structural perspective in terms of their notion of dualism, the marginalization of certain economic activities and actors, and on the commanding role of rural-urban migration for informality. However, they differed on the root causes of informality and on its importance in income generating efforts and economic growth roles. The Voluntarist Perspective also focuses on informal entrepreneurs who deliberately seek to avoid regulations and taxation but, unlike the legalist school, does not blame the cumbersome registration procedures. The Voluntarists argue that street vendors choose to operate informally after weighing the cost benefits of informality relative to formality. The Voluntarists pay relatively little attention to the economic linkages between street vending business and formal business but subscribe to the notion that street vending businesses pose unfair competition for formal businesses because they avoid formal regulations, taxes, and other costs of production and service. They argue that street vending business should be brought under the formal regulatory setting in order to increase the tax base and reduce the unfair competition with formal businesses (Chen, 2012).

\section{BREIF ACCOUNT OF THE INFORMAL SECTOR IN ETHIOPIA}

About 21.3\% of the Ethiopian population (i.e., 24.46 million) is urban. According to the Central Statistical Authority report (2012) the growth rate of urbanization in Ethiopia is about $4 \%$, the national population growth is about $2.7 \%$. Recently, in particular, the ruralurban migration is quite high to the extent it becomes beyond the carrying capacity of urban areas in terms of municipal services, infrastructure and the economy at large. According to the World Bank (2007), the Ethiopian urban economy is segmented into three, namely, a large (formal) public sector, a small (formal) private sector, and a large informal sector. The informal economy in Ethiopia is estimated at about 38.6\% of the GDP compared with an average $38.4 \%$ for SSA and 38\% for all low income countries (IMF, 2013). The informal economy in Ethiopia is estimated to accommodate $50-60 \%$ of the urban employment (UNDP, 2012) and about 42\% of these informal sector operators earn their livelihoods from microenterprises (CSA, 2005). The figure for the neighbor Kenya, for instance, is significantly higher than that of Ethiopia. The 2015 Kenya economic survey report confirms that the informal sector had the largest share of employment accounting for $82.7 \%$ of the total employment.

Unemployment has been a long standing problem in urban areas of Ethiopia. About $90 \%$ of rural-urban migrants to the cities are not employed in the formal sector due to lack of skill, working premises and capital. As a result, they are forced to engage in the informal sector (CSA, 2013). Small entrepreneurs in the informal sector do not have the capacity to get support and finance from formal financial institutions. Instead they rely on saving and credit schemes to get finance needed for business ventures. Those who are engaged in informal activities depend mainly on finance from families, friends, and a little personal savings (CSA, 2006). In general, the sector is under multiple challenges which are 
exacerbated by several factors. Amidst of these problems, the sector sustains and proliferates in the streets of the urban centers.

Table 1 Urban labor force employed by the informal sector

\begin{tabular}{|c|c|c|}
\hline Percent & Year & Source \\
\hline 50 percent & 1998 & CSA, 1999 \\
60 percent & 2002 & CSA, 2003 \\
38.5 percent & 2005 & CSA, 2006 \\
25.8 percent & 2012 & CSA, 2013 \\
\hline
\end{tabular}

Source: Reproduced from Chalachew (2018:40)

Founded in 1886, the capital of Ethiopia, Addis Ababa, is one of the oldest and largest cities in Africa. The current population of the city is estimated to be 4.79 million. The city is located at about the center of the country and has been a pool of people from all corners of the country in search of better opportunities, including employment. The high rate of rural urban migration accounts for more than 40 percent of the growth. The recurring trend of political instability and absence of employment opportunities in other parts of the country has forced many people to migrate to the city. The trend has been further exacerbated by lack of proper development policies that would create ample job opportunities hence curb the current excessive migration.

Table 2 Population of Addis Ababa (10 years data)

\begin{tabular}{|c|c|c|c|}
\hline Year & $\begin{array}{c}\text { Population No (in } \\
\text { Millions) }\end{array}$ & Density $(\mathrm{km} 2)$ & $\begin{array}{c}\text { Growth Rate } \\
\text { (in Percent) }\end{array}$ \\
\hline 2020 & 4.79 & & 4.40 \\
\hline 2019 & 4.59 & & 4.36 \\
\hline 2018 & 4.40 & & 4.36 \\
\hline 2017 & 4.22 & & 4.36 \\
\hline 2016 & 4.04 & & 4.37 \\
\hline 2015 & 3.87 & & 4.37 \\
\hline 2014 & 3.71 & & 4.36 \\
\hline 2013 & 3.55 & & 4.38 \\
\hline 2012 & 3.40 & & 4.35 \\
\hline 2011 & 3.26 & & 4.38 \\
\hline
\end{tabular}

Source: Macrotrends.net (2020)

Not only the trend of an overall increase in population was very high, but the rate at which it increases was also quite high. The highest rate was recorded in the years between 1968 and 1984 (i.e., between $4.72 \%$ and $4.99 \%$ ) followed by the next highest increase in the recent years between 2008 and 2020 (i.e., between 4.37\% and $4.40 \%$ ). This remarkable increase in the population of the City was basically attributed to an ever increasing trend of rural-urban migration. And it is a matter of deep concern to discuss about what would happen to the people that migrate into the City in large numbers. And more seriously, it is a matter of profound concern to think about what should be done in the political, economic and demographic domains and other pertinent components of overall development policies in order to curb the exodus of people from rural areas.

Table 3 Population of Addis Ababa (rates of increase) 


\begin{tabular}{|c|c|c|}
\hline Year & $\begin{array}{c}\text { Range of Percentage Increase } \\
\text { in Population }\end{array}$ & Remark \\
\hline $2008-2020$ & $4.37-4.40$ & The range of lowest rates of increase \\
\hline $1995-2007$ & $2.05-2.58$ & \\
\hline $1985-1994$ & $3.91-3.98$ & The range of highest rates of increase \\
\hline $1968-1984$ & $4.72-4.99$ & \\
\hline $1950-1967$ & $2.65-3.05$ & \\
\hline
\end{tabular}

Source: Macrotrends.net (2020)

In the year 2002, a study by the Association of Ethiopian Microfinance Institutions (AEMI) estimated that the informal sector in Addis Ababa to be fifty one percent (51\%) of the productive economy (UN, 2006). While the informal economy in Ethiopia is stated as considerably large, for every ten registered (formal) firms there are almost four nonregistered (informal) firms. This number is significantly lower compared to Ethiopia's regional counterparts. For instance, the average for Sub-Saharan Africa is 7.5. Ethiopian entrepreneurs also indicated one of the lowest rates of firms in Ethiopia (only 11\%), identifying competitors in the informal sector as a major constraint. This number is over three times higher in Sub-Saharan Africa (37\%) (ibid).

A survey conducted by the Central Statistical Authority (CSA) two decades back, showed that there were 584,913 informal sector operators and 2,731 small-scale manufacturing industries, employing a total of 739,898 people. The survey further indicated that informal activities concentrate in micro and small manufacturing and trade (47\%) and services sectors (42\%). According to the 1997 data by the CSA, the size of labor force engaged in the informal sector activities and small-scale manufacturing industries was eight times larger than that of the medium and large-scale manufacturing industries. Recent estimates of the informal sector in Ethiopia place the sector at 69\% in Addis Ababa, compared to the national average, which lies below 15\% (World Bank 2014, as cited in Amsale, 2017).

Within the scope of the informal sector, street vending comprises a widespread economic activity in Addis Ababa. The urban poor, mainly immigrants, are typically involved in this informal activity. Street vending in the city is believed to significantly contribute to employment opportunities. As an integral part of the urban economy, street businesses provide a wide variety of goods at bargaining prices. One finds street vendors in almost all the districts of the city selling goods and services without obtaining permit, giving receipts or paying taxes. Some of the vendors operate at sidewalks, busy roadways or at bus terminals where many people are likely to gather. Others walk around the city selling goods or services without a traceable place to operate. The vital question at this juncture is that, had it not been by means of informal economic engagements, notably street vending, what would happen to the livelihood of a large number of local immigrants that enter the city almost on daily basis?

\section{STREET VENDING}

Many scholars have different definitions to describe the street vending business. Street based self-employment has been described as a poverty trap or a stepping stone for 
migrant youth in Africa (Bezu and Holden, 2015). The operators, street vendors, could be stationary and occupy space on the pavements or other public areas, or could be mobile and move from one area to another carrying their wares in baskets on their heads, or could sell their wares in moving carts and vehicles. The term "street vendor" in English is typically used interchangeably with "street trader," "hawker," and "peddler" (Moser, 1978). Street vendors are the persons who sell goods in public space as well as those who provide services in public spaces without having a permanently built structure but with a temporary static structure or mobile stall (ILO, 2013; Bhowmik, 2005; 2007). Other scholars define street vending as all non-criminal commercial activity dependent on access to public space, including trade from unlimited locations and mobile vending (ibid; Moser, 1978).

Street vending is an ancient and important occupation found virtually in every country around the world (Broomley, 2000). Even in developed economies, street vendors continue to play a big role in the informal economy. It is difficult to obtain accurate and reliable information on the street vending sector, resulting in a lack of initiation and implementation of appropriate policy interventions unlike other informal sector economic activities. There has also been inconsistent report among policy makers on how they perceive street vending activities. Street vendors are viewed as a nuisance and menace which does not motivate to conduct research. However, according to ILO (2002), Mitullah (2003), and Adhikari (2011), many countries around the world have in recent years realized the importance of street vending for the urban economies and considered it as a way of poverty reduction and started to conduct research as an appraisal of its contributions to socioeconomic and environmental concerns.

Street vending has been practiced in several different ways. Most vendors sell goods, but some sell services, and some sell both of them. Some vendors are fixed in one location, using a kiosk or a heavy stall which remains in the same location for months or even years and is locked up and left under the supervision of a watchman when not in use. Others use heavy mobile stalls which are pushed from a storehouse into the sales position at the beginning of the working day and pushed back at the end. Still others are fixed in location, but simply lay their merchandise out on the ground or on a plastic sheet. Mobile vendors may use wheels to move merchandise or operate on carts or, more commonly, carry their merchandise themselves. Some mobile vendors sell to passers-by, some do door-to-door delivery, and still others hawk from building to building (Bromley, 2000).

Major cities of the world are experiencing swelling growth of street vending coupled with substantial increase in the number of street vendors (Mitullah, 2003; Adhikari, 2011). The major factors identified as generic causes of street vending are linked with lack of employment and rising poverty in rural and urban areas that have pushed people to leave their villages and communities to sell goods in the streets (ILO, 2013). These migrants do not have the education or the skills to find gainful jobs in the formal sector. Low productivity in agriculture in LDCs forces millions of people to migrate to urban areas in search of better opportunities. Contrary to the classical assumptions of Arthur Lewis, the "surplus labor" from rural areas cannot be fully absorbed by the urban (formal) industrial sector of the LDCs as it is not yet ready to engage more people due to its infant stage of growth. Rather, the immigrants settle for work in the informal sector. The reasons for the spread of the informal sector differ from one country to the other owing to the economic, demographic, social and political backgrounds of the countries concerned. 
Street vending activities flourish as a result of slow rate of economic growth coupled with a faster rate of population growth (mainly caused by rural-urban migration). The formal sector cannot create job opportunities for the surplus labor supply; hence people would resort to work in the informal sector. For the dualists, the sluggish economic growth that does not match the population growth is an important cause for the informal sector to flourish (Chen, 2012). Todaro (1997) argues that many factors are behind rural-urban migration in developing countries. Demographic, environmental (including climatic hazards) social, cultural and communication factors (like improved transportation and modernization impacts of the media) trigger high rate of rural-urban movement of people. The creation of one job in the formal sector attracts more than one migrant. Due to push and pull factors, the rate of migration from the rural to the urban areas is greater than that of the number of jobs generated by the formal sector. For the neo-liberalists, tax burden and bureaucratic red tape are important causes for the proliferation of street vending activities and the informal economy at large. People would hence prefer the informal sector to avoid red tape, rigorous regulations and tax burden. The legalists also believe that the informal sector is driven by micro entrepreneurs who deliberately want to avoid costs of formally operating. Informality is thus the result of micro-entrepreneurs' choice and decision to operate illegally (Maloney, cited in Chen, 2012). The formal sector normally creates more of high-skill jobs; hence those without the skills are forced to join the informal sector. The micro and small business sectors generally create more jobs than the formal sector.

Some scholars (particularly form the school of structuralism) argue that informality in production relation is the inherent character of the capitalist system (Moser, 1978; Castells and Portes, 1989). In modern times, economic crises also lead to increased unemployment through loss of jobs in the formal economy and inversely to increased employment in the informal sector. Greater number of people who lost their job turned to street vending as a possible source of income. When enterprises in the formal sector are downsized or shut down, due to economic restructuring and economic crisis, the workers who are laid-off and cannot find alternative formal jobs often end up working in the streets (Chen, 2012). A typical case in point is the closures, downsizing or mergers in industries of South Asia, which forced most of the laid-off workers to join the informal sector in general and street vending in particular (Dendukuri, 2007).

\section{METHODS OF DATA COLLECTION AND PRESENTATION}

Most of the vendors in the streets do not have stable selling places. Vendors that provide some services that require ground spaces like shoe shining services (together with vending other items) are the ones to be traced in fixed places. Therefore, the possible way to contact sample vendors is on random (chance) basis as they are accidentally encountered on the streets. Random contacts have been made to collect data from 120 sample respondents. Four data collectors, all of them higher education students, are engaged in the data collection process.

Brief checklist of questionnaire was administered to solicit information from the busy and, at times, impatient street vendors. Most of them are not interested to take time leisurely and talk non-business matters. They are kin only to see that passersby purchase their merchandise. Hence the checklist had to be precise, focusing on elemental issues 
alone. The street scene does not allow surveyors to go beyond the basic affairs. In many cases vendors expect surveyors to buy certain goods. In this survey context, the data collectors are expected to make a swift attempt to promptly obtain data as per the checklist. They are also expected to switch to other vendors in the vicinity in case the ones encountered are not willing to participate. The duty was relatively easier with some of the vendors who are engaged in shoe shining for the very reason indicated earlier.

On top of the checklist, physical observation in the district of Megenagna was valuable addition to firmly grasp the manner and street processes of vending. Physical observation helped enrich the primary data collected through the questionnaire. The data are presented using tables and graphs. Analysis and interpretation are in due course complemented with narrative descriptions, explanations and presentations.

\section{EVIDENCE FROM THE MEGENAGNA DISTRICT OF ADDIS ABABA}

Megenagna, the hub of commercial and transport activities, is one of the city centres in Addis Ababa. The area is among the city centres very well known for a crowd of street vending.

The most common form of street vending is whereby the seller just holds his/her items by hand using some big plastic sheet and try selling it wherever people are abundant along the streets. This common and mobile form of vending is relatively widespread and risky for both the vendors and buyers. Street business is in sheer violation of many laws, including traffic, trade and health-related rules and regulations. Code enforcing groups constantly chase vendors; force them for nonstop running and hiding. Those in case caught could lose their items and thrown into jail at least for a short period of time. The daily experience of street vending is thus characterized by chase-and-run situation between law enforcers (locally known as Denb Askebari) and the street vendors. One can also imagine the random prevalence of corrupt practices, particularly, bribes at this juncture. This being the case, however, we still witness an increasing number of people, particularly the youth, joining the sector.

Table 4 Personal particulars: original residence, gender, marriage and education

\begin{tabular}{|c|c|c|c|c|}
\hline Original residence: & $\begin{array}{c}\text { Addis Ababa } \\
\text { (AA) }\end{array}$ & Around AA & $\begin{array}{c}\text { North of } \\
\text { AA }\end{array}$ & $\begin{array}{c}\text { South of } \\
\text { AA }\end{array}$ \\
\hline No: & 14 & 10 & 29 & 67 \\
\hline Gender of vendors: & \multicolumn{4}{|c|}{ No (percent) } \\
\hline Male & \multicolumn{4}{|c|}{$68(56.67)$} \\
\hline Female & \multicolumn{4}{|c|}{$52(43.33)$} \\
\hline \multicolumn{5}{|l|}{ Family status of vendors: } \\
\hline Married & \multicolumn{4}{|c|}{15} \\
\hline Single & \multicolumn{4}{|c|}{115} \\
\hline \multicolumn{5}{|l|}{ Education status of vendors: } \\
\hline No formal education at all & \multicolumn{4}{|c|}{$10(8)$} \\
\hline Grade 1-6 (primary education) & \multicolumn{4}{|c|}{$56(46.6)$} \\
\hline Grade 7-10 (secondary education) & \multicolumn{4}{|c|}{$42(35)$} \\
\hline Preparatory and higher education & \multicolumn{4}{|c|}{$12(10)$} \\
\hline
\end{tabular}

Sample surveys indicate that most of the vendors are from areas south of the city (i.e., southern Ethiopia) followed by those who came from regions of the north. The 
number of vendors who came from areas around the city (immigrants) and from the city itself (residents) are by far lower than those who came from the south and the north. More than eighty percent of the vendors do have formal education of primary or secondary levels. Only ten percent of the vendors have no any formal education. The traditional anticipation and ensuing narrative that operators in the informal sector are mainly with no formal education can be frequently attacked as more people with formal education are joining the sector. As per the data from the samples, about ten percent of the vendors have attended preparatory and higher education levels. Given the absence of job opportunities in the formal sector, the informal sector will be a readily available economic shelter for the school dropouts and even the large army of graduates from the mushrooming regional universities. Major Reasons for Joining Street Vending

As has been seen earlier the driving forces behind street vending are manifold. Several factors may push people to leave their villages in search of means for livelihood and better opportunities. For many of the urban poor, particularly for the immigrants, street vending is the sole means of income generation and livelihood. Few of them, of course, use it as a means of supplementary income to support family resources and efforts.

The immigrants and the existing (resident) urban poor resort to do some sort of job in order to generate income. Most of them are compelled to join the informal sector, particularly street vending, for certain viable reasons. One key reason stressed by the vendors was the relatively small capital requirement of street vending. Vendors did not have fixed property of value to be held as collateral to get finance from credit institutions. Lack of access to credit facilities is mentioned as the key reason for vendors to join the sector and stay through street vending until they are able to save the bare minimum required to even think of becoming a legal trader. According to the respondents, another basic reason for vendors to join and stay in street vending is lack of suitable and commercially viable trading outlets or shops. The current rental price of shops in Addis Ababa is virtually unaffordable to many people thinking of joining licensed business leave alone to those fresh vendors with meager financial and material recourses. This reality forces even experienced vendors to work on streets for an indefinite period of time.

The streets of Megenagna are very much crowded with vendors who came to the city from different parts of the country. The vendors, notably the immigrants, had different ways of joining the informal businesses. Some of them came to the city through peer influence and family advice whereas the others made their own decisions to migrate to the city and eventually join street vending as a viable means of livelihood. The social network is very important for joining street vending particularly for the new comers. This could be one reason that we observe young vendors, both male and female, speaking local languages of distinct ethnic groups concentrate in certain areas of the streets. Their original places are the same; they work together and mostly share rented shelters with their closer friends and relatives. Living together, beyond its role to share burdens of rental costs, is a means to wield strong social support within that small group.

Street vendors offer assorted goods at relatively lower prices for pedestrians and other walking customers. Many people in Addis are these days accustomed to "shopping" at the streets. Closings (new as well as used), shoes, plastic products and household appliances are some of the commodities available for buyers at fair prices. Some of the vendors carry one type of item (for instance, shoes or simple electronic items) whereas others carry assorted commodities that are meant for different purposes. Those vendors 
who work on fixed spaces carry relatively large volume of assorted commodities. They also provide shoe shinning services along with vending. For the mobile ones, most of the goods are easily portable as packed in large plastic bag and can be easily carried away when sudden raids are made by the law enforcing officers. Clothes, wears for women and men, are the common commodities carried by the mobile vendors. As can be seen on the graph, most of the vendors carry multiple (assorted) items and clothing (new and used). Presence of large crowd of vendors in a given space is partially the result of the size and volume of items carried by an individual vendor.

Figure 1 Merchandise in the streets

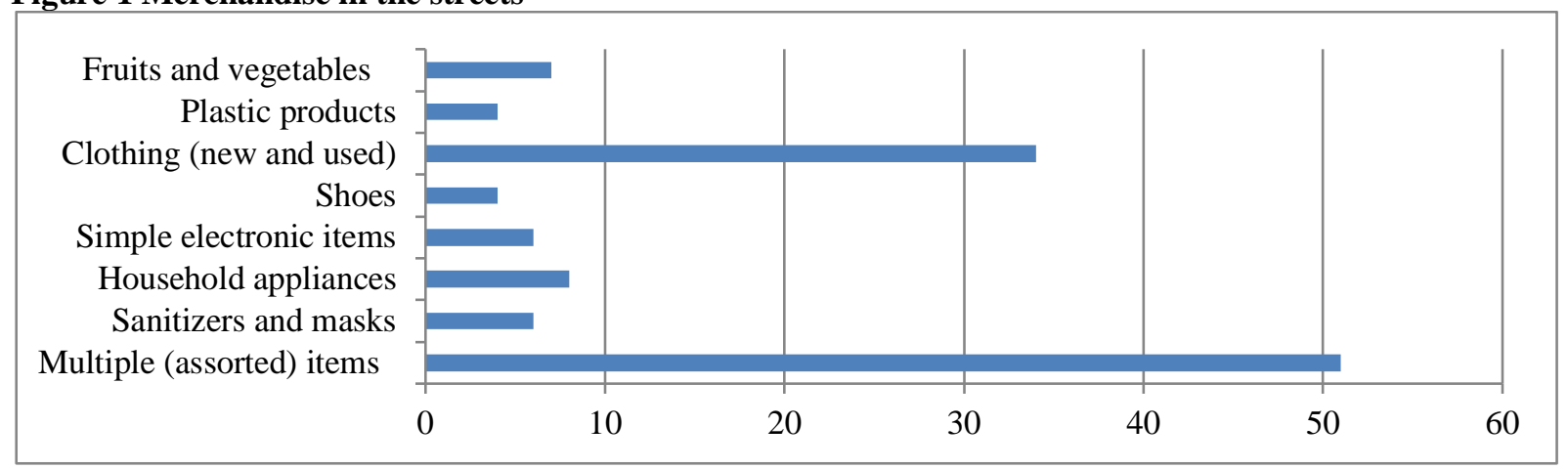

\section{Capital: Initial and Current}

People require some amount of capital, basically finance, to start any business. With this financial capital they may acquire tools, machines, inventory, raw materials, labor and working premises as the case may be. The idea of labor encompasses factors of skill and experience required to perform a particular economic activity. Street vending does not under normal circumstances entail all of these as fundamental requirements. Vendors rather require certain amount of money as an initial capital to start street business of their choice. Initially, they acquire small inventory of items with the money they have. Gradually they can acquire more money and inventory depending on the circumstances. The combination of favorable business climate, business caliber and personal behavior of individual vendors in handling and managing their meager financial and material resources would help them gradually build more and more asset.

Table 5 Capital and daily average income of individual vendors

\begin{tabular}{|c|c|c|c|c|}
\hline $\begin{array}{c}\text { Capital } \\
\text { (in Birr) }\end{array}$ & $\begin{array}{c}\text { No of vendors } \\
\text { (Initial Capital) }\end{array}$ & $\begin{array}{c}\text { No of vendors } \\
\text { (Current Capital) }\end{array}$ & $\begin{array}{c}\text { Daily average } \\
\text { income }\end{array}$ & No \\
\hline Less than 1000 & 54 & 9 & Below 10 Birr & 0 \\
\hline $1001-3000$ & 21 & 19 & $10-50$ Birr & 24 \\
\hline $3001-5000$ & 18 & 25 & $101-200$ Birr & 36 \\
\hline $5001-7000$ & 11 & 21 & $201-300$ Birr & 20 \\
\hline $7001-9000$ & 9 & 17 & Above 300 Birr & 0 \\
\hline $9001-11000$ & 7 & 14 & -- & - \\
\hline $11001-13000$ & 0 & 7 & -- & - \\
\hline $13001-15000$ & 0 & 5 & - & - \\
\hline Above 15000 & 0 & 3 & & \\
\hline Total & 120 & 120 & & \\
\hline
\end{tabular}


Majority of the respondents were found to have initial capital of less than 1000 Birr. Up to 3000 Birr, the graph of initial capital (the number of vendors within that bracket) is greater than the graph of the current capital. Those vendors who have current capital of below 3000 Birr are new comers to the business. Few of the respondents reported that they have current capital closer to 15000 or above 15000 Birr; and those were vendors who sell items of relatively higher value like clothing, home appliances and electronic materials. With this level of capital and small amount of daily income, vendors (except few of them) are unlikely to save much and expand the business or make alternative moves to change the type of business. "Business expansion" in this context is not constrained by the availability of meager capital alone but also by the nature and working place of the business itself. Vendors are either mobile or relatively permanent. They work informally and have no any legal and regulatory coverage. If there is some level of business expansion in the true sense it is only for the non mobile vendors. Hence most of the vendors are likely to remain at subsistence level till they grow and change the nature and modality of the business. Current capital of a vendor is an aggregate of available finance and estimated value of items to be sold.

Street vendors normally use their personal savings as start-up capital to begin street business. In addition to this, however, there are other sources including, family transfers and informal credits. Moreover, some of the vendors reported that they got the initial money from their relatives and friends as grants; together constitute a sum slightly lower than the amount secured through informal credits. Vendors bear the burden of settling credits on top of the money required for living expenses and running the business. Personal savings followed by family transfers become very important sources of initial capital for most of the vendors. In Ethiopia, particularly in the capital city, people join street vending to be self-reliant, to support their family and more importantly due to the absence of opportunities to engage in the formal sector. Immigrant vendors are of the opinion that street vending in Addis Ababa generates by far better income than they used to get in their original villages. Because of these many people, essentially the youth, are attracted to come to the city to join street business activities.

Street vendors maintain the business and sustain livelihood with what they earn on daily basis. The street vendors who sell assorted items together with shoe shining services are likely to get more income. Ray and Mishra (2011) argued that despite the low incomes generated from vending activities, vendors do not wait for handouts and/or employment opportunities from the government or engage in begging or stealing. This is a clear sign that street vending is not only a form of economic engagement and income distribution but also an effective means of addressing social problems emanating from population pressure and absence of opportunities in the formal sector. Street vending does not only enable the marginalized to meet their minimum daily expenses, but also teaches and inspires the youth to value work.

\section{Challenges of Street Vending}

Street vendors face a lot of financial constraints and non-financial obstacles. The main challenges confronting street vendors include shortage of finance, absence of the right 
to trading space, security, transport and municipal services, environmental problems and routine disputes with the local governments. Street vending is perceived as a major crisis and an eye-sore in the urban authorities and criticized for causing or contributing to a number of social ills that negatively affect cities. Beyond these, street vendors are entrenched in a web of complex livelihood challenges. In Africa, local authorities were major challenges to the development of street vending activities. Most of them use restrictive policies, by-laws and regulations initially intended to regulate and control the growth of indigenous enterprises. The restrictions make vending principally illegal, and view vendors as responsible agents for making cities dirty, causing air pollution and obstructing traffic. Hence street vendors are perceived as a public nuisance. The policies did not totally appreciate the role of street vending in an urban economy (Palmer, 2007).

In Addis Ababa, street vendors are confronted with multitude of challenges, related both to their day to day lives and the business itself. Escalating costs of living due to inflation causes lack of appropriate place of living often situated at distant places from the working place. This is the key problem challenging the lives of most of the street vendors. In terms of living standard, the rampant inflationary situation (which is estimated to be $15.81 \%$ in 2019, 20.6\% in 2020 and $11.47 \%$ in 2021) in the country poses at least two key challenges: (i) difficulties beyond the capacity of vendors to have dissent living place and (ii) difficulties to make affordable expenses on routine consumption. Vendors often acquire rented houses in groups at remote and slum areas of the city. Vendors rely on street foods that are relatively cheaper than foods available in restaurants of even lower grades.

Figure 2 Challenges facing street vendors and street vending

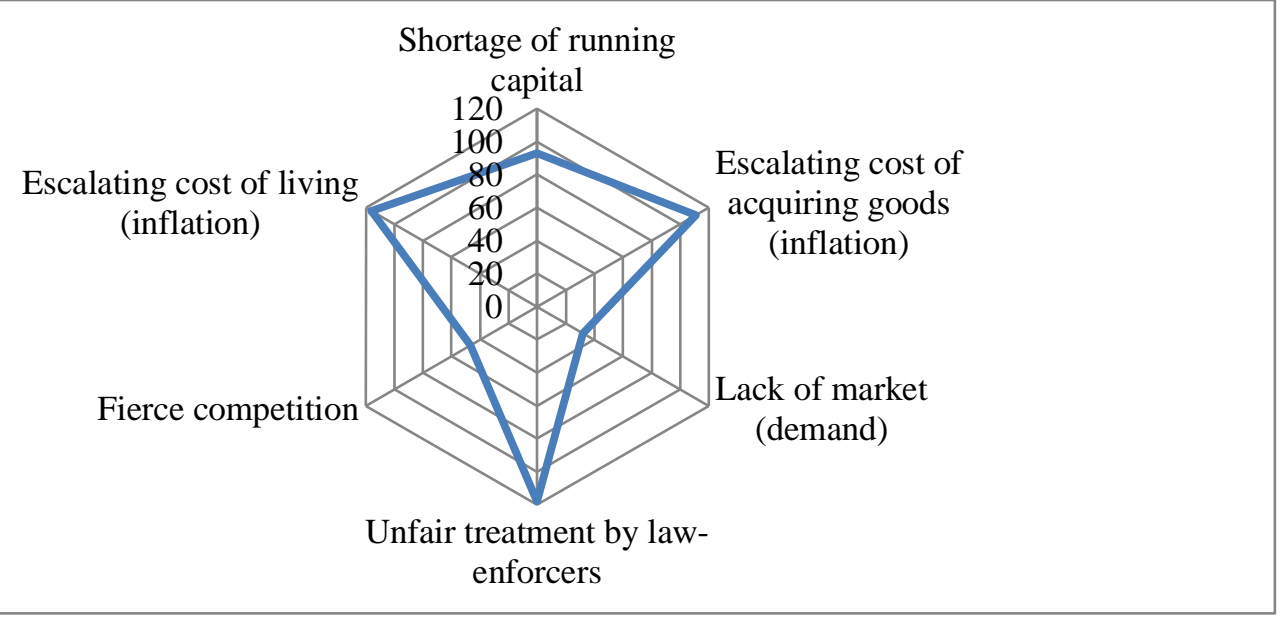

Shortage of running capital (finance) coupled with escalating costs of acquiring goods, unfair treatment by law-enforcement officers and fierce competition are the major challenges related to street vending. Unfair treatment by law-enforcers, followed by escalating cost of acquiring goods (as induced by inflation), are the key challenges of street vending. The initial capital was so small that vendors could not elevate it to the level of sufficient capital to run the business. Inflation and daily requirements for other expenses restrain the money to be available for acquiring sufficient inventory. In order to let more money into the business, vendors have to constrain their daily living expenses. Law 
enforcers are reported to be the day to day impediments, not only because they enforce rules and regulations but also they exercise maltreatment and corrupt practices. The vendors are not licensed hence normally expected to be watched out by the law enforcers. However, the manner of treatment by the officers goes beyond the level expected by the local government and the rules and regulations set to guide the same. Of course, the government of Ethiopia has exerted relentless efforts to bring informal businesses to formal, licensed ones. Despite this effort, street vending is increasing at an alarming rate as a result of multiple economic, political, demographic (particularly migration) and related factors. These days one can observe main streets of Addis crowded with mass of vendors and buyers starting from mornings to late afternoons till the night.

The number of buyers is likely to offset the competition among vendors. By the virtue of their proximity to walking customers, street vendors have more product accessibility than the shop owners. Demand is normally active since vendors offer lower prices for most of the goods. The table below shows variations on selected goods between street vendors and shop owners. There is a considerable price difference on the same products, vendors' prices being below that of formal shopping prices. Vendors have the advantages of not paying for licenses, rents, workers, the VAT and annual trade taxes that would have impacts on prices of commodities. Such price differences on same products make many people prefer to buy from the streets vendors.

Table 6 Comparison: street Vs shop prices

\begin{tabular}{|c|c|c|c|}
\hline Commodity & Vendor price & Shop price & Difference \\
\hline Face mask 1 & $5-10$ birr & $10-25$ birr & $5-15$ birr \\
Face mask 2 & $20-50$ birr & $50-70$ birr & $20-30$ birr \\
Banana & $15 \mathrm{br} / \mathrm{kg}$ & $20-25 \mathrm{br} / \mathrm{kg}$ & $5-10 \mathrm{birr}$ \\
\hline Shirt & $150-225 / \mathrm{pc}$ & $250-300$ & $25-100 \mathrm{birr}$ \\
\hline A pair of trousers & $200-350 \mathrm{birr}$ & $300-500$ & $150-300 \mathrm{birr}$ \\
A pair of socks & $15-20 \mathrm{birr}$ & $25-30 \mathrm{birr}$ & 10 birr \\
\hline Electric coffee boilers & 450 birr & $600 \mathrm{birr}$ & $150 \mathrm{birr}$ \\
A pair of shoes & $250-350$ birr & $500-650 \mathrm{birr}$ & 10 birr \\
Soft paper & 10 birr & 20 birr & $10-20$ birr \\
\hline
\end{tabular}

On the other hand, street vendors also cause many challenges on the operation of municipal governments, pedestrians and drivers. Pedestrians are annoyed by the encroachment of sidewalks. At some places it is difficult to walk straight. People then will have to pass the narrow aisles between seller stalls walking sideways. When the sidewalks are too crowded people are forced to step onto the road to walk which is a dangerous exercise. Drivers and other road users dislike street vendors because they cause jams on traffic and pedestrian sidewalks. One of the major effects of street vending in Addis Ababa is the disruption in pedestrians' free movement and vehicle traffic. Vendors usually trade on sidewalks and suddenly chased by code enforcers, who often confiscate their belongings. To escape from the officers, the vendors would rush into the main roads thereby creating a possibility of traffic jams and accidents to themselves and pedestrians in some cases.

Shop owners dislike street vendors for their illegal use of the shops 'front sidewalks", which the street vendors modify to suit their own needs. This modification often involves semi-permanent roof to protect their wares from the sun and rain, usually in 
the form of blue/industrial plastic tents, which obstructs sun light from shining on the shops and hampers the flow of fresh air. All this deprive the sidewalk of its convenience and deters walking customers into the shops, hence reducing the business of formal shop owners. Formal businesses are directly threatened when street vendors carry similar goods to that of the shops. Formal shop owners define street vendors as direct and unfair competitors, since street vendors steal their customers out in front before the customers enter the market. As was mentioned above, vendors do not pay taxes so have an option of selling products for much lower price than legal traders which results in reduction in sales volume of the latter as people will usually prefer cheaper products with comparable quality. This puts a toll on profitability of legal, taxpaying traders. There is an unfair advantage at the disposal of vendors which needs to be checked for healthy functioning of the market system. Street vending has negative effects on buyers since people cannot return or get substitutes for the products purchased in case of defects as the vendors do not have stable places and are often in constant run away from code enforcing officers. It is important to identify two types of street vendors on the basis of the venue in which they conduct businesses. One is those who work in fixed places along the streets and the other is those without fixed places. The latter group poses problems to the city government as vendors cannot be traced for statistical, registration, monitoring and support purposes. Even those who are assumed to have relatively fixed places can suddenly move away to any part of the city.

\section{Brief Remarks on the Legal Aspect}

Another effect of street vending is the illegal or unregulated nature of the business whereby the government loses tax payment which could have been collected had the transactions took place legally. Local governments are forced to allocate huge budgets to hire as many officers as possible to control street businesses. The budgets could have been used for other development purposes if street businesses were at their minimum. Municipal governments have tried to set guidelines as to how one can operate on legal basis while trading in the streets with registration and identification badge (through article 53 of the business code). As per this article, the vendors can obtain a badge ascertaining the fact that they are recognized traders by the local authorities which gives them some sense of security while trading on the streets. This was intended to create favorable conditions for them to be more productive. Related benefit is the possibility of obtaining designated and regular trading spaces for those who are registered. Vendors (including new vendors) of similar products would converge in one venue so that buyers could easily spot them. The effort has been relatively successful with regard to some shoe shiners who need a permanent place to settle and work. These shoe shiners are also engaged in vending other commodities on the spots designated to them.

Registered street vendors are expected to pay taxes. However, they would not pay taxes until they reach a certain level of financial stability, experience and business growth. This gives vendors the opportunity to gradually learn formal and licensed trade. The registered vendors indicated that registration could have a positive correlation with generating more income on regular basis. Since registered, their income started growing regularly and some of them even joined daily ekub in their vicinity. Ekub is informal saving association, in which members (usually traders) contribute (save) certain amount of money 
and take the collected amount in a rotating fashion. The saving doesn't of course bear any interest. Yet there is some amount of fee paid by the members as an administrative or running cost. The most noticeable advantage of Equb is that it encourages saving and members will get a sum of money required for an economic purpose (Elias, 2014; Gebrehiwot and Wolday, 2006)

The majority of street vendors, however, do not have the basic knowledge of the requirements for operating on streets based on the guidelines set to govern the street businesses. This creates a problem whenever code enforcing units try to implement the rules. The consequence is that many vendors lose their property for not respecting the rules. Street vendors are not registered as per the guidelines for different reasons: they don't have kebele, they do not believe that they would get ideal trading spaces, they simply don't want to come to the regulated business perhaps for the fear of paying taxes. Kebele is the lowest administrative unit of the city government

Majority of the vendors are not permanent residents of the City which creates a problem when they try to get local government (kebele) ID, which is one of the basic requirements to operate as a registered street vendor. Because of this vendors are not able to obtain registration badge, consequently end up vending illegally (i.e., without registration) in the streets and often chased by the law enforcers (the denb Sakelaris and other regular police officers). In the last 15 years or so, the Ethiopian government has made relentless efforts to bring informal businesses to formal. However, that was mainly possible when such businesses were located on fixed places. Mobile businesses like street vending have been very difficult to register and regulate. Given the recurrent increase in the number of immigrants to the city, the task of regulating street vending has been almost impossible.

\section{Conclusion}

The focus of this study was on street vending in one of the busiest hubs of Addis Ababa, very well known as Megenagna. This area of the city is characterized by heavy concentration of street vending and other formal economic activities. The recurring trend of political instability and absence of employment opportunities in the country has forced many people to migrate to the capital city. The trend has been further exacerbated by lack of proper development policies intended to create ample job opportunities hence curb the current enormous migration to the city. People join street vending to be self-reliant, to support their family and due to absences of opportunities to engage in the formal sector. Immigrant vendors are of the opinion that street vending in Addis Ababa generates by far better income than they used to get in their original villages. Because of these many people, essentially the youth, are attracted to the city to join street business activities.

The streets of Megenagna are very much crowded with vendors who came to the city from different parts of the country. The social network is very important for joining street vending particularly for the new comers. This could be one reason that we observe young vendors, both male and female, speaking local languages of distinct ethnic groups concentrate in certain areas of the streets. The key reasons for joining the sector include the relatively small capital requirement of street vending, lack of access to credit facilities, and lack of suitable and commercially viable trading outlets or economically affordable shops. For many of the urban poor, particularly for the immigrants, street vending is the sole means of livelihood. 
Street vendors were found to start with small sum of capital. They use their personal savings, family transfers and informal credits as start-up capital to begin the business. With this level of capital and small amount of daily earning, vendors are unlikely to expand the business or make alternative moves to change the type of business. Street vendors offer goods at relatively lower prices for pedestrians and other walking customers. Many people in Addis are these days accustomed to "shopping" at the streets. Most of the goods in the streets are easily portable as packed in large plastic bag and can be easily carried away when sudden raids are made by the law enforcing officers. Presence of large crowd of vendors in a given space can be taken as a function of the size and volume of items carried by an individual vendor.

Shortage of running capital (finance) coupled with escalating costs of acquiring goods, unfair treatment by law-enforcement officers (locally known as Denb Askebari) and fierce competition are the major challenges related to the business on streets. Some of the law enforcers are blamed to exercise maltreatment and corrupt practices. The manner of treatment by the officers goes beyond the level expected by the city government and the rules and regulations set to guide the same. Despite government's effort to regulate, street vending is increasing at an alarming rate as a result of multiple economic, political, demographic (particularly migration) and related factors.

On the other hand, street vendors also cause many challenges on the operation of municipal governments, pedestrians and drivers. One of the major effects of street vending in Addis Ababa is the disruption in pedestrians' free movement and vehicle traffic. Not only that, informal trading also reduces the business of formal shop owners. Formal businesses are directly threatened when street vendors offer similar goods carried by the shop-owners. Formal shop owners define street vendors as direct and unfair competitors, since street vendors steal their customers out in front before the customers enter the regular market. Vendors do not pay taxes hence can sell products for much lower price than legal traders which results in reduction in sales volume of the latter as people will usually prefer cheaper products with comparable quality.

Another effect of street vending is the illegal or unregulated nature of the business whereby the city government loses tax income which could have been collected had the transactions taken place legally. The city government is forced to allocate huge budgets to hire as many officers as possible to control street businesses. The city government has tried to set guidelines as to how one can operate on legal basis while trading in the streets with registration and identification. Related benefit is the possibility of obtaining designated and regular trading spaces for those who are registered. Vendors (including new vendors) of similar products would converge in one venue so that buyers could easily spot them. Registered street vendors are expected to pay taxes. However, they would not pay taxes until they reach a certain level of financial stability, experience and business growth. This gives vendors the opportunity to gradually learn formal and licensed trade. For the last 15 years or so, the Ethiopian government has made relentless efforts to bring informal businesses to formal, licensed ones. However, that was mainly possible when such businesses were located on fixed places. Mobile businesses like street vending have been very difficult to register and regulate. Given the recurrent increase in the number of immigrants to the city, the task of regulating street vending has been extremely difficult. 


\section{References}

1. Adhikari, D. B. (2011). Income generation in informal sector: A case study of the street vendors of Kathmandu Metropolitan City. Economic Journal of Development Issues, 1-14, https://doi.org/10.3126/ejdi.v13i0.7193

2. Amsale A. 2017. Street vending and local authorities in Addis Ababa city: challenges and the way forward. August 16th 2017.

3. Barnes, T. (2012). Marxism and informal labour. Journal of Australian Political Economy, The, (70), 144-166.

4. $\quad$ Bezu, S., \& Holden, S. T. (2015). Street based self-employment: A poverty trap or a stepping stone for migrant youth in Africa?.

5. Bhowmik, K. Sharit (2005). Street Vendors in Asia, A Review in Economic and Political Weekly, 2256-2264

6. Bhowmik, S. K. (2007). Street vending in urban India: the struggle for recognition. In Street Entrepreneurs (pp. 114-129).Routledge.

7. Bhowmik, S.K., 2005. Street vendors in Asia: a review. Economic and political weekly, 2256-2264.

8. Bromley, R. (2000). Street Vending and Public Policy: A Global Review, in International Journal of Sociology and Social Policy, 20 (1/2), 1-28, https://doi.org/10.1108/01443330010789052

9. Castells, M., \& Portes, A. (1989). World underneath: The origins, dynamics, and effects of the informal economy. The informal economy: Studies in advanced and less developed countries, 12.

10. Castillo-Palacio, M., Batista-Canino, R. M., \& Zuñiga-Collazos, A. (2020). The Cultural Practices that Influence on the Entrepreneurial Activity: An Empirical Study from the Globe Project Cultural Dimensions. Scientific Annals of Economics and Business, 67(4), 517-532.

11. Central Statistical Agency.(2004). Urban biannual employment unemployment survey, volume 319, Statistical bulletin, Addis Ababa.

12. Chalachew G D. (2018). The Urban Informal Economy in Ethiopia: Theory and Empirical Evidence.

EASSRR, Vol XXXIV, No. 1(January 2018) https://doi.org/10.1353/eas.2018.0001

13. Chaundhuri and Mukhopadhyay (2009). Revisiting the Informal Sector: A general equilibrium approach, 1st ed. New York: WIEGO

14. Chen, M. A. (2005). Rethinking the informal economy: Linkages with the formal economy and the formal regulatory environment (Vol. 10, pp. 18-27).United Nations University, World Institute for Development Economics Research.

15. Chen, M. A. (2012). The informal economy: Definitions, theories and policies (Vol. 1, No. 26, pp. 90141-4). WIEGO working Paper.

16. Chen, M., Vanek, J., and Heintz, J. (2006). Informality, gender and poverty: A global picture. Economic and Political Weekly, 2131-2139.

17. Cross J. and Morales, A. (2007). Introduction: locating street markets in the modern/postmodern world. In Street Entrepreneurs (pp. 23-36). Rutledge.

18. CSA (2003). Urban National Informal Sector Survey, Central Statistical Agency, Addis Ababa.

19. CSA (2005). Labor Market Survey, Federal Democratic Republic of Ethiopia, Addis Ababa: Central Statistical Authority.

20. CSA (2006). Report on the 2005 National Labor Force Survey, Central Statistical Agency, Addis Ababa.

21. CSA (2012).Report on Urban Employment Survey, Central Statistical Agency, Addis Ababa.

22. Dendukuri I A (2007). Study of Street Vending Across the Globe, in International Journal of Advanced Research

23. Elias B. (2014). The role of micro and small enterprises (MSEs) in Local Economic Development (LED), with a focus on the wood-work MSE value chain. A PhD Dissertation (UNISA)

24. $\quad$ Elias B. (2005). Role of Micro and Small Enterprises in Local Economic Development: The case of Awassa, in Local economic Development in Africa, Enterprises, Communities and Local Government, edited by GE Tegegne and B Helmsing. St Maarten: Shaker Publishing.

25. Hart, K. (1973). Informal income opportunities and urban employment in Ghana. The journal of modern African studies, 11(1), 61-89.https:/ /www.researchgate. net/publication/

26. ILO, (1972). Employment, Incomes and Equality, Geneva: International Labor Organization. 
27. ILO (2013) WIEGO. Women and Men in the Informal Economy: A Statistical Picture (Second edition). Geneva: International Labor Organization, 2013.

28. ILO. (2002). Women and Men in the Informal Economy: A Statistical Picture. Geneva: International Labor Organization.

29. ILO (2009). The Informal Economy in Africa: Promoting Transition to Formality: Challenges and Strategies., Geneva.

30. ILO. (2013). Measuring informality: A statistical manual on the informal sector and informal employment. International Labor Office.

31. LEDNA (2011). The Importance of Informal Economy for Local Economic Development (LED) in Africa.

32. Loop, THM van der, (2000). The Impact of Globalization on the Organization of Production, Micro and Small Enterprises and Labor: with special emphasis on Africa. Working No.6. RLDS, AAU, Ethiopia

33. Mengistu, T. and Jibat, N. (2015). Street vending as the safety-net for the disadvantaged people:

The case of Jimma Town. International Journal of Sociology and Anthropology, 7(5), pp. 123-137. 2015

34. Mitullah, W. V. (2003). Street vending in African cities: A synthesis of empirical finding from Kenya, Cote d'Ivoire, Ghana, Zimbabwe, Uganda and South Africa. Ray Bromley Street vending and public policy: a global review, Department of Geography and Planning, State University of New York at Albany

35. Macrotrends.net. (2020). Macrotends.net/cities/20921/addis-ababa/population. 2010-2020 Macrotrends LLC.

36. Moser, C. O. (1978). Informal sector or petty commodity production: dualism or dependence in urban development? World development,6(9-10), 1041-1064.।

37. Muiruri, P. (2010). Women Street Vendors in Nairobi, Kenya: a Situational and Policy Analysis within a Human Right Framework. Ethiopia, Addis Ababa: OSSREA.

38. Palmer, R. (2007) Skills for work; from skills development to decent livelihoods in Ghanaecs rural informal economy. International Journal of Educational Development 27. 397-420

39. Pederson, P O. (2000). A Macro-Perspective on Small Enterprise Growth in Southern Africa, in Local Economies in Turmoil. The Effects of Deregulation and Globalization.

40. $\quad$ Pinki, K. (2015). Issues and Challenges for Street Vendors in Delhi.

41. Todaro, M . (1997). Economic Development. 6th edition. London: Addison Wesley Longman Limited.

42. Todaro, M. and Smith S C (2012). Economic Development. 11th ed. Boston: AddisonWesley/Pearson.

43. UNDP (2012). The Informal Sector in the Jordanian Economy.

44. UN-Habitat (2007). A Look at the Urban Informal Economy. Habitat Debate, 13(2), 1-24.

45. UN-Habitat (2009). Local Economic Development. Nairobi, 10 June 2009. Creative Commons Attribution - Non Commercial - No Derivatives 4.0 International License. 